Investigation of a new chiral auxiliary derived chemoenzymatically from toluene: Experimental and computational study

\begin{tabular}{|r|l|}
\hline Journal: & Canadian Journal of Chemistry \\
\hline Manuscript ID & cjc-2016-0327.R1 \\
\hline Manuscript Type: & Article \\
\hline Complete List of Authors: & $\begin{array}{l}\text { Snajdr, Ivan; Brock University, Chemistry } \\
\text { Froese, Jordan; Brock University, Chemistry } \\
\text { Dudding, Travis; Brock University } \\
\text { Horakova, Pavlina; Brock University, Chemistry } \\
\text { Hudlicky, Tomas; Brock University, Chemistry }\end{array}$ \\
\hline Keyword: & $\begin{array}{l}\text { chiral auxiliary, biocatalysis, computational study, Diels-Alder } \\
\text { cycloaddition, Davis hydroxylation }\end{array}$ \\
\hline \multicolumn{2}{|c}{} \\
\hline
\end{tabular}

SCHOLARONE

Manuscripts 


\title{
Investigation of a new chiral auxiliary derived chemoenzymatically from toluene: Experimental and computational study
}

Ivan Šnajdr, Jordan Froese, Travis Dudding, Pavlína Horáková, and Tomáš Hudlický*

Department of Chemistry and Centre for Biotechnology, Brock University, St. Catharines, ON L2S 3A1, Canada

thudlicky@brocku.ca

\begin{abstract}
A tricyclic chiral auxiliary, prepared from the enzymatically derived cis-arene dihydrodiol metabolite of toluene, was investigated as a means of asymmetric induction in several different reactions. The auxiliary was converted to an oxaziridine and its utility in hydroxylation, providing low levels of enantiomeric excess, was compared with that of Davis's oxaziridine. Insight into the origin of stereoinduction in this reaction is provided and is based on computational Monte Carlo Multiple Minimum (MCMM) searches using the OPLS3 forcefield. The use of the auxiliary group in the alkylation of appended esters proved disappointing. Diels-Alder cycloaddition of an acrylate, derived from the auxiliary group, with cyclohexadiene furnished a mixture of diastereomeric adducts in essentially equal amounts. The adducts were separated and the corresponding enantiomeric residues were isolated with good enantiomeric excess. Evidence of reasonable levels of asymmetric induction in the above processes was lacking. Experimental and spectral data are provided for all key compounds.
\end{abstract}




\section{Key Words}

Chiral auxiliary, biocatalysis, computational study, Diels-Alder cycloaddition, Davis hydroxylation

\section{Introduction}

Almost two decades ago, we subjected several arene cis-dihydrodiols, namely $\mathbf{1}$, 2 , and 3, derived from styrene, toluene, and (2-bromoethyl)benzene, respectively to intramolecular Diels-Alder reactions. These efforts led to the total synthesis of zeylena $(5)^{1}$ and to an effective model study for the synthesis of morphine fragments $\mathbf{7}^{2}$ and $\mathbf{9},{ }^{3}$ as shown in Figure 1 .

The model studies toward morphine eventually led to a very efficient synthesis of ent-hydromorphone $(\mathbf{1 2})^{4}$ by employing a similar intramolecular cycloaddition strategy, shown in Figure 1. 


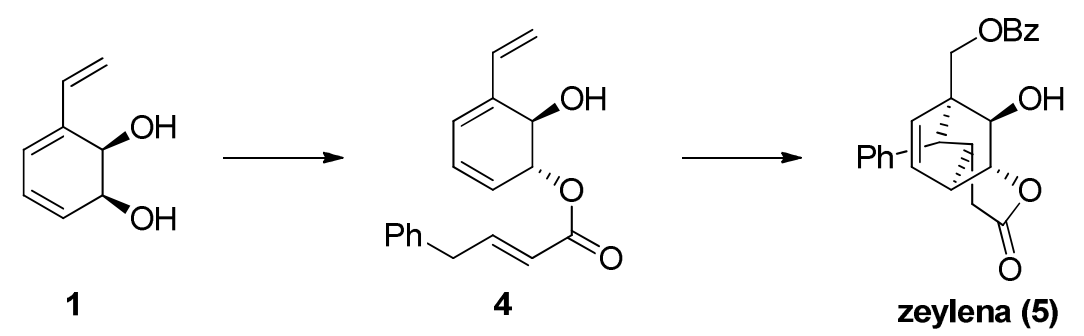

Initial model study towards morphine:

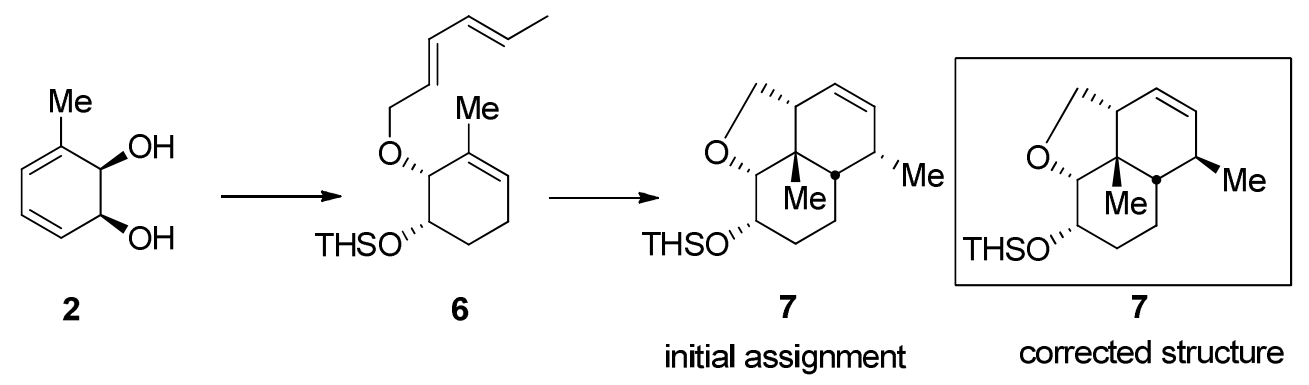

Advanced model study towards morphine:<smiles>OC1C=CC=C(CCBr)C1O</smiles>

3

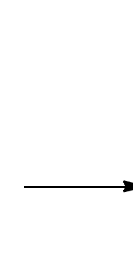

THSO

8<smiles>C/C=C\CCO[C@H]1C(CCNC(=O)O)=CCC[C@H]1O</smiles>

8

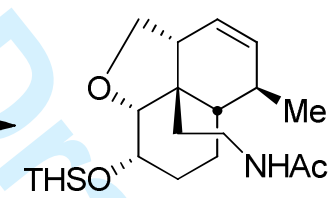

9<smiles>[X]/C=C/c1ccc(O)c(OC2C(CC[X])=CCC[C@H]2OC(C)C)c1</smiles>
(12)

Figure 1. Synthesis of zeylena (5) and ent-hydromorphone (12) via intramolecular [4+2] cycloaddition.

In addition, in 1992 we utilized compound 13, Scheme 1, derived from the enzymatic metabolite of styrene, in a proof of absolute stereochemistry of new metabolites derived from o- and $m$-chlorostyrenes (14). ${ }^{5}$ We suggested in $1993^{6}$ that rigid structures of type $\mathbf{1 3}$ or $\mathbf{1 5}$ might be useful as auxiliary groups for 
reactions such as Michael additions, alkylations, Diels-Alder cycloadditions, hydroxylations, and as organocatalysts.<smiles></smiles>

1<smiles>CC1=CC=CC(O)C1O</smiles>

2

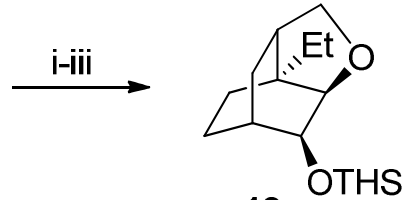

13

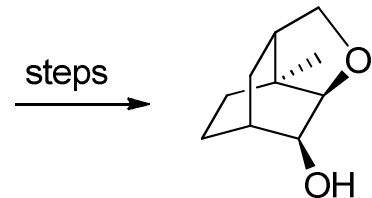

15<smiles>CC#CC</smiles>

14

Reagents and conditions: (i) $\mathrm{NaH}$, allyl bromide, $\mathrm{THF},-20^{\circ} \mathrm{C}$; (ii) $\mathrm{CCl}_{4}, 80{ }^{\circ} \mathrm{C}$; (iii) $\mathrm{H}_{2}, \mathrm{Pd} / \mathrm{C}, 45$ psi.

Scheme 1: Proof of absolute stereochemistry of $14 .^{5}$

We did not return to the investigation of compounds such as 15 until two decades later, with expectations of useful levels of asymmetric induction that would be derived from its use as a chiral auxiliary. The efficient and easily scalable synthesis of 15 from toluene further supported our expectations. In this paper we report some rather disappointing results with regard to low level of asymmetric induction for several common processes.

\section{Results and discussion}

Synthesis of auxiliary groups. We reasoned that the hindered exo-face of 15 would result in rigid transition states and limited facial access for the functionalization of groups attached to the core. We chose to examine Davis hydroxylation, alkylation of enolate anions, and intramolecular Diels-Alder 
cycloadditions. The reactions were designed to produce known substances for immediate comparison. The synthesis of the chiral auxiliary group, shown in Scheme 2, begins with the enzymatic dihydroxylation of toluene with $E$. coli JM109 (pDTG601A), a strain that over-expresses toluene dioxygenase. ${ }^{7}$<smiles>CC1=CC=CC(O)C1O</smiles>

2<smiles>[SiH3]OC1C2CC3CC1C3O2</smiles>

18

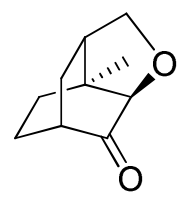

20

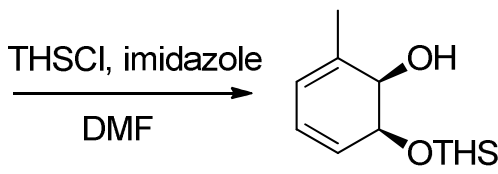

16

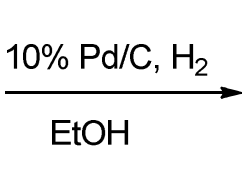

$\underset{\mathrm{THF}, \text { reflux }}{\stackrel{\mathrm{Ti}(\mathrm{O}-\mathrm{iPr})_{4}, \mathrm{TsNH}_{2}}{\longrightarrow}}$



19

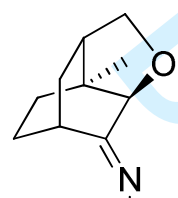

21 Ts



17



15

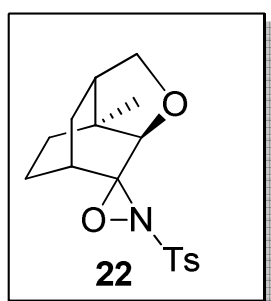

Scheme 2: Synthesis of oxaziridine 22.

The synthesis started from enantiomericaly pure cis-dihydrodiol 2 obtained from the enzymatic dihydroxylation of toluene. ${ }^{8}$ Diol $\mathbf{2}$ was selectively protected with a bulky dimethylthexylsilyl chloride (THSCl) on the less hindered 1-position to afford silyl ether 16 in $91 \%$ yield, as shown in Scheme 1. When tertbutyldimethylsilyl chloride was used instead of $\mathrm{THSCl}$, migration of the protecting group was observed in the subsequent step. Alcohol 16 was then alkylated with allyl bromide, and the resulting allyl ether spontaneously underwent intramolecular Diels-Alder reaction upon work-up. To complete the conversion, the crude reaction mixture was dissolved in THF and heated to reflux. Column chromatography of the reaction mixture provided tricyclic silyl ether 18 in $83 \%$ 
yield. The alkene in 18 was then reduced using $10 \% \mathrm{Pd} / \mathrm{C}$ in a Parr shaker to afford compound 19 in 93\% yield.

The deprotection of the dimethylthexylsilyl group proved to be problematic. The standard procedure, using 3 equivalents of TBAF in dry THF at room temperature, provided only $45 \%$ conversion. When the reaction mixture was heated to reflux, the conversion was complete, but the yield after chromatography was only $42 \%$. When the amount of TBAF was decreased to 1.4 equivalents, the yield increased to $72 \%$ after 3 hours of reflux in dry THF. Alcohol 15 was then oxidized with pyridinium chlorochromate in $\mathrm{CH}_{2} \mathrm{Cl}_{2}$ to provide ketone 20 in $91 \%$ yield.

Formation of imine $\mathbf{2 1}$ was rather complicated. Ketone $\mathbf{2 0}$ was treated with tosylamine in the presence of various titanium catalysts, and the use of $\mathrm{TiCl}_{4}$ or $\mathrm{TiCl}_{4} / \mathrm{Ti}(\mathrm{O}-\mathrm{Pr})_{4}$, in refluxing $\mathrm{CH}_{2} \mathrm{Cl}_{2}, 1,2-\mathrm{DCE}$, or $\mathrm{THF}$ did not lead to any conversion. The use of $\mathrm{Ti}(\mathrm{O}-\mathrm{iPr})_{4}$ in refluxing $\mathrm{CH}_{2} \mathrm{Cl}_{2}$ provided $65 \%$ conversion with $35 \%$ of the starting material recovered. The best results were obtained using $\mathrm{Ti}(\mathrm{O}-\mathrm{PPr})_{4}$ in refluxing $\mathrm{THF}$, which resulted in complete conversion after 5 days. Imine $\mathbf{2 1}$ was not stable to silica gel, decomposing to ketone 20. Purification was accomplished by extraction and rapid filtration through a short plug of silica, and the compound was used immediately in the next step. Imine $\mathbf{2 1}$ was oxidized in a biphasic system of toluene and aqueous $\mathrm{K}_{2} \mathrm{CO}_{3}$ using Oxone ${ }^{\mathrm{TM}}$ as an oxidant. The resulting oxaziridine 22 was also not stable to silica gel, decomposing to ketone 20. Purification of an analytical sample was possible on deactivated silica gel $\left(10 \% \mathrm{w} / \mathrm{w} \mathrm{H}_{2} \mathrm{O}\right)$.

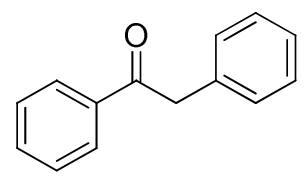

23

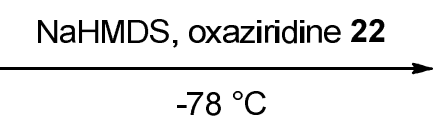

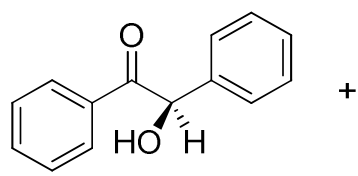

24

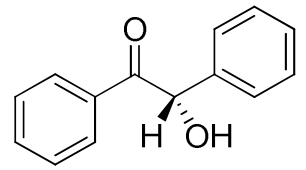

25

Scheme 3: Hydroxylation with oxaziridine 22.

Davis hydroxylation attempts. Deoxybenzoin 23 was selected as a model compound for enantioselective hydroxylations. The use of (-)-Davis oxaziridine 
led to the production of $\mathbf{2 4}$ in $85 \%$ yield with $95 \%$ ee. ${ }^{9}$ We followed the same procedure using NaHMDS and oxaziridine 22 in dry THF at $-78{ }^{\circ} \mathrm{C}$, Scheme 3. Purification of the reaction mixture afforded $85 \%$ yield of $24(R)$ - and $25(S)$ benzoin with a disappointing $16 \%$ ee in favor of $\mathbf{2 5}$, which was the opposite enantiomer than the one obtained from the reaction with (-)-Davis's oxaziridine. This result my be surprising in view of the similarity of the structure of oxaziridine 22 to that of Davis's oxaziridine. We have not assigned the stereochemistry of 22 but assumed that the oxaziridine had the endo- configuration. Modeling of the transition state for the hydroxylation of 23 also assumed the endo-22 and the prediction is clearly in favor of $s i-23$ that would lead to $(S)-25$, which is agreement with the experimental results (see Figure 3 and discussion of calculations below).



Scheme 4: Alkylation with auxiliary 15.

Alkylation attempts. To test enantioselective alkylation, we prepared phenylacetyl ester 26 from alcohol 15 in $74 \%$ yield. Alkylation using lithium diisopropylamide and methyl iodide at $-78{ }^{\circ} \mathrm{C}$ provided ester $\mathbf{2 7}$ in $84 \%$. Ester 27 was then hydrolyzed using $\mathrm{LiOH}$ in aqueous methanol, affording 2phenylpropanoic acid $\mathbf{2 8 ^ { 1 0 }}$ in $86 \%$ yield, Scheme 3 . The analysis of the specific rotation revealed an essentially racemic mixture of $(R-)$ and (S-) enantiomers with $5 \%$ ee. 


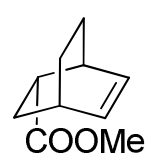

$31 \mathrm{a}$
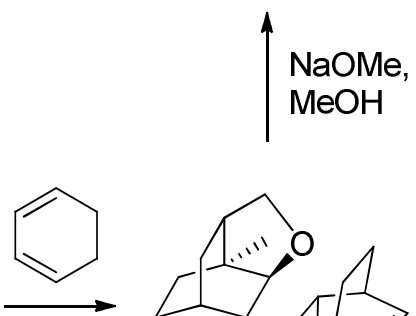

toluene

15
$\mathrm{Et}_{3} \mathrm{~N}, \mathrm{THF}$

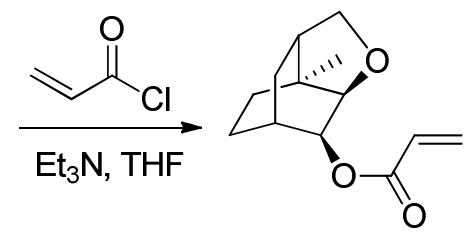

29

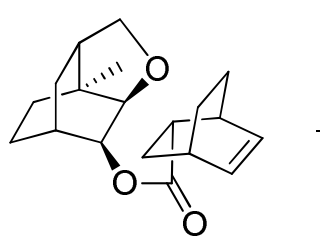

$30 a$

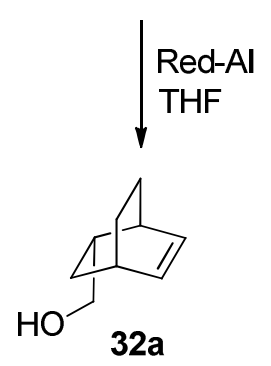

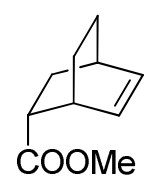

31b


30b

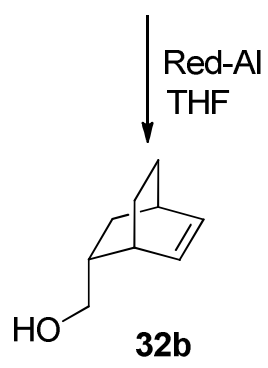

Scheme 5: [4+2] cycloaddition with auxiliary 15.

[4+2] Cycloaddition attempts. To investigate the asymmetric induction in [4+2] cycloaddition reactions, acryloyl ester 29 was prepared from alcohol 15 in $87 \%$ yield by treatment with acryloyl chloride and triethylamine. The subsequent [4+2] cycloaddition was performed in a sealed tube in toluene at $155{ }^{\circ} \mathrm{C}$, Scheme 4 . Purification of the reaction mixture by column chromatography provided two compounds, $30 \mathrm{a}$ and $\mathbf{3 0 b}$ in nearly equal amounts, indicating that almost no asymmetric induction took place.

Initially, these compounds were separated and treated with sodium methoxide to obtain the known methyl esters (31a, 31b). ${ }^{11}$

${ }^{1} \mathrm{H}-\mathrm{NMR}$ spectrum of 31 a showed a mixture of $95 \%$ endo and $5 \%$ exo-isomers.

Similarly, $\mathbf{3 1 b}$ showed a mixture of $90 \%$ endo and $10 \%$ exo-isomers. The specific 
rotations were also different $-\mathbf{3 1 a}$ was +1.2 and $\mathbf{3 1} \mathbf{b}$ was -39.5 . The literature value for $99 \%$ enantiomerically enriched sample of $31 \mathrm{a}$ is +95.6 . $^{11}$

To determine the composition of the above-mentioned products, and to ensure that no epimerization took place during methanolysis of $30 \mathrm{a} / 30 \mathrm{~b}$, each adduct was separately treated with Red-Al to obtain starting alcohol 15 and alcohols 32a and 32b. ${ }^{12}$ After chromatographic separation of these alcohols, the specific rotation of both was measured. The specific rotation of starting alcohol 15 remained unchanged, as expected. The values corresponding to the new alcohols $\mathbf{3 2 a}$ and $\mathbf{3 2 b}$ however, were different: $\mathbf{3 2 a}$ was -10.5 and $\mathbf{3 2 b}$ was +7.7 . The literature value for $99 \%$ enantiomerically enriched sample of $32 a$ is $+8.7^{12}$ and for $\mathbf{3 2} b$ is -10.7 . $^{13}$

From these results, we assumed that $\mathbf{3 2 a}$ and $\mathbf{3 2} \mathbf{b}$ each represent an individual enantiomer of the endo-isomer. To confirm this hypothesis, chiral HPLC analysis of both samples $32 a$ and $\mathbf{3 2 b}$ was performed, and a racemic standard was prepared, as shown in Scheme 6.



33

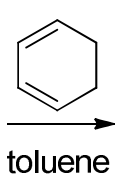

toluene

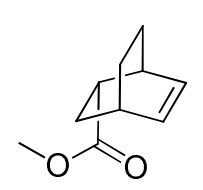

rac-34

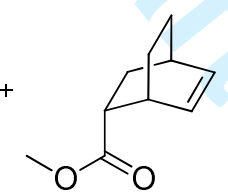

-34
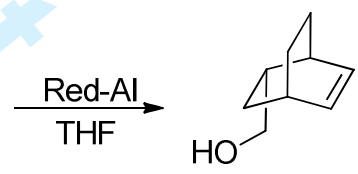

rac-32

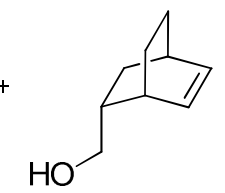

$\mathrm{HO}$

Scheme 6: Synthesis of rac-32.

Chiral HPLC analysis of the racemate (rac-32) showed two peaks at $22.3 \mathrm{~min}$ and $23.0 \mathrm{~min}$, respectively, and a minor peak corresponding to the exo-isomer (likely formed by partial epimerization of the ester) at $23.8 \mathrm{~min}$. The analysis of compound 32a displayed one major peak at $22.7 \mathrm{~min}$, whereas sample $\mathbf{3 2 b}$ showed a different peak at $22.0 \mathrm{~min}$, representing the other enantiomer.

Based on these chiral HPLC results, we prepared both endo-isomers that were easily separated using standard column chromatography. Unfortunately, the nearly $1: 1$ ratio of $\mathbf{3 0 a}$ to $\mathbf{3 0 b}$ indicates that no significant asymmetric induction 
was achieved during the cycloaddition with enantiomeric excess estimated as $<5 \%$.

\section{Computational studies.}

Disappointed by the outcomes of the three reactions studied, namely alkylation, dihydroxylation, and Diels-Adler cycloaddition, we turned to computational modeling in order to gain insight into the factors contributing to the low levels of asymmetric induction offered by our tricyclic chiral auxiliary. To this end, we focused on understanding the stereoselectivity conferred by oxaziridine 22 in the dihydroxylation reactions affording (S)-benzoin (25) in 16\% ee, as opposed to the alkylation or the Diels-Alder reactions. The basis for this decision stemmed from the rationale that little, if any, meaningful insight into the origin of stereoselectivity could be gained by studying the latter two cases because of the extremely low stereoselectivity observed (See the SI Section for additional information). Thus, working under the conceptual framework of the Hammond-Leffler postulate with the imposed caveat that oxaziridine oxygen transfer occurred early on the reaction coordinate, Monte Carlo Multiple Minimum (MCMM) searches using the OPLS3 forcefield as implemented in the Schrödinger MacroModel program were used to rationalize the stereoinduction offered by $22 .{ }^{15}$ More specifically, we performed a MCMM simulation initiated from a geometry conforming to a $\mathrm{C} \cdot \cdots \mathrm{O}$ bond forming precomplex for addition of an enolate derived in situ from 23 to the oxaziridine ring of 22. Imposed on this system were a $\mathrm{C} \cdot \bullet \mathrm{O}$ bond distance constraint of $2.8 \AA$, while the coordinates of the ${ }^{*} \mathrm{C}$, ${ }^{*} \mathrm{O}$, and ${ }^{*} \mathrm{~N}$ of the oxaziridine ring were frozen, as shown in Figure 2.

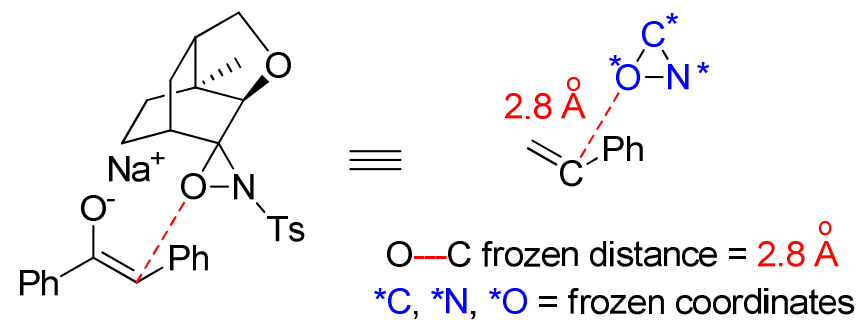

Figure 2. Imposed constraints for MCMM search. 
This search provided a conformer distribution $(5.02 \mathrm{kcal} / \mathrm{mol}$ cut-off threshold) that revealed a $0.35 \mathrm{kcal} / \mathrm{mol}$ energetic difference between the lowest energy sivs. re-stereofacial addition modes (si-23 and re-23), which favored the formation of (S)-benzoin. ${ }^{16}$ Notably, this is in reasonable agreement with the experimental formation of (S)-benzoin in $16 \%$ ee (predicted $=29 \%$ ee), shown in Figure 3. Perhaps worth noting is the fact that the C-O-N (bond-making/bond-breaking) angle in si-23 and re-23 was displaced from the $180^{\circ}$ metric that one might expect based on the theoretical work of Bach, which is not at all surprising given the use of precomplexes vs. transition states for this analysis. ${ }^{17}$ 

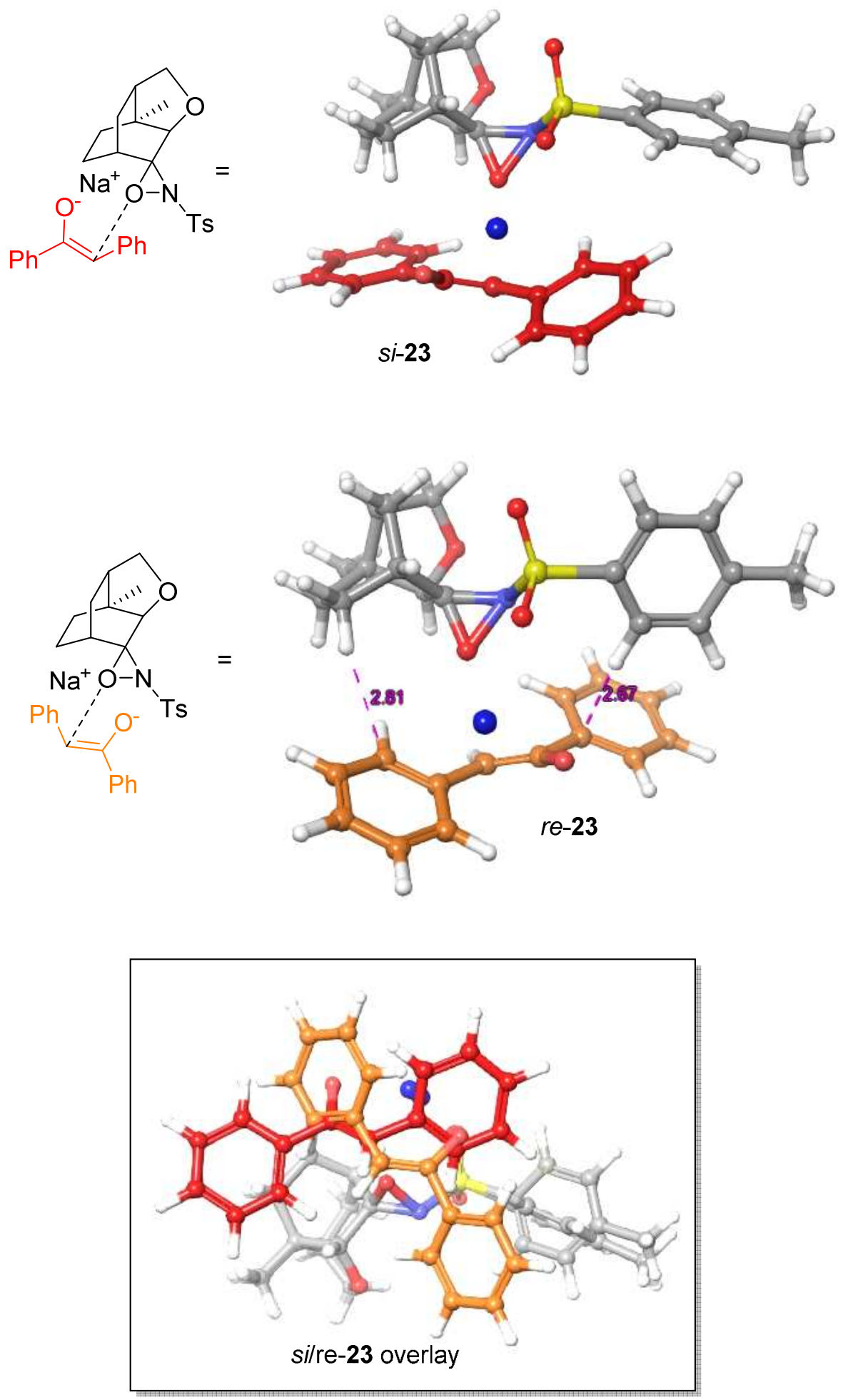

Figure 3. Lowest energy si- vs. re-stereofacial addition modes (si-23 and re-23) and superimposition 
As for the factors contributing to stereoselectivity a superimposition (maximum atom deviation $=0.5 \AA$ ) of these two stereofacial addition modes offered visible clues (see silre-23 overlay, Figure 3). Foremost in this regard was the flipped, circa $180^{\circ}$, orientations of the enolates relative to the oxaziridine ring, which resulted in subtle differences in terms of negative van der Waals contacts (i.e., steric interactions). For instance, the displaced edge-to-face $\mathrm{C}-\mathrm{H} / \pi$ aryl arrangement between the tosyl ring and the enolate phenyl group of re-23 introduced an unfavorable $\mathrm{C}-\mathrm{H} \cdots \mathrm{C}$ contact measuring $2.67 \AA$, which is markedly below the summed radii of $C$ and $H(C=1.7 \AA, H=1.2 \AA) .{ }^{18}$ In addition, an unfavourable steric relationship between a hydrogen of the tricyclic core of $\mathbf{2 2}$ and the nearby phenyl of the enolate was also present in re-23 $(\mathrm{C}-\mathrm{H} \cdots \mathrm{C}$, distance $=2.81 \AA$ ). Conversely, the offset $\pi-\pi$ alignment in si-23 did not result in a comparable steric interaction between the tosyl ring and the proximal phenyl of the enolate with the closest interaction being a $\mathrm{C}-\mathrm{H} \bullet \cdot \circ \mathrm{C}$ contact (distance $=2.89$ $\AA$ ). Meanwhile no unfavourable van der Waals contacts were found between the tricyclic motif and enolate in si-23. At that stage, to provide for a more evolved and in-depth vision of the elements governing stereoselectivity the optimization of structures si-23 and re-23 to first-order saddle points at the density functional theory (DFT) level was attempted, which, unfortunately were unsuccessful. Notwithstanding, despite the fact that our chiral auxiliary did not provide good levels of asymmetric induction, it is noteworthy that the conceptual understanding that has emerged from this study offers some promise as a point of departure for designing new chiral auxiliaries. Indeed, the MCMM modelling approach employed herein is fast (processing time on a standard PC desktop computer $=2$ min) and simple to execute. Accordingly, its use as springboard for DFT studies and employment as a rapid method for assessing stereoselective trends provided by chiral auxiliary oxaziridine reagents is ongoing and developments on this front will be reported.

\section{Conclusions}


The chiral auxiliary group 15, prepared from the homochiral diene-diol derived chemoenzymatically from toluene (2), was investigated for asymmetric induction in several reactions: Davis-type hydroxylations utilizing its oxaziridine derivative, alkylation of appended esters, and [4+2] cycloadditions of an appended acrylate with cyclohexadiene. The very low levels of induction observed in hydroxylation reactions were disappointing. No induction was observed in alkylation or cycloaddition reactions, although enantiomers of bicyclic alcohols $31 \mathrm{a}$ and $\mathbf{3 1 b}$ were isolated after separation of the diastereomeric adducts. We attribute the lack of any reasonable induction to the freely rotating side chain of appended functionalities. The expected structural similarity of $\mathbf{1 5}$ to chiral auxiliary groups derived from camphor and other rigid bicyclic systems was clearly not evident in the results obtained. The computational study confirmed the reasons for the low levels of induction observed especially in the case of hydroxylation.

For additional computational data, and ${ }^{1} \mathrm{H} N M R /{ }^{13} \mathrm{C}$ NMR spectra for all key compounds, see Supplementary Information.

\section{Acknowledgements}

The authors are grateful to the following agencies for financial support of this work: Natural Sciences and Engineering Research Council of Canada (NSERC) (Idea to Innovation and Discovery Grants), Canada Research Chair Program, Canada Foundation for Innovation (CFI), TDC Research, Inc., TDC Research Foundation, the Ontario Partnership for Innovation and Commercialization (OPIC), and The Advanced Biomanufacturing Centre (Brock University).

Pavlína Horáková, a visiting exchange student from Palacky University in Olomouc, Czech Republic, thanks the European Social Funds for funding by a grant (CZ.1.07/2.4.00/31.0130).

\section{Experimental section}




\section{General experimental.}

All nonaqueous reactions were conducted under an inert (nitrogen or argon) atmosphere, using standard Schlenk techniques for the exclusion of moisture and air. All solvents were distilled unless otherwise noted. Analytical thin-layer chromatography was performed on silica gel $60 \AA 250 \mu \mathrm{m}$ TLC plates with F-254 indicator. Flash column chromatography was performed using silica gel (230-400 mesh). Melting points are uncorrected. Optical rotation was measured in $1 \mathrm{dm}$ cell at $25{ }^{\circ} \mathrm{C}$ and $589 \mathrm{~nm}$, concentration in $\mathrm{g} / 100 \mathrm{~mL}$ on Perkin-Elmer 341 polarimeter. IR spectra were obtained on Bruker ALPHA FT-IR spectrometer. ${ }^{1} \mathrm{H}$ and ${ }^{13} \mathrm{C}$ spectra were recorded on Bruker $300 \mathrm{MHz}$ and/or 600 $\mathrm{MHz}$ spectrometers. All chemical shifts are referenced to TMS or residual nondeuterated solvent. Data for proton spectra are reported as follows: chemical shift (multiplicity [singlet (s), doublet (d), triplet (t), quartet (q), quintet (quint), and multiplet $(m)]$, coupling constants $[\mathrm{Hz}]$, integration). Carbon spectra were recorded with complete proton decoupling and the chemical shifts are reported in ppm (C). Mass spectra and high resolution mass spectra were performed by the analytical division at Brock University. Combustion analyses were performed by Atlantic Microlabs, Atlanta, GA.

\section{(-)-(3aS,7S)-3a-Methyloctahydro-3,6-methanobenzofuran-7-ol (15)}

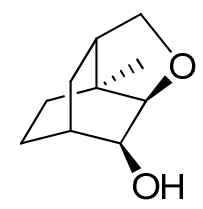

A solution of compound $19(17.5 \mathrm{~g}, 56.3 \mathrm{mmol})$ in an anhydrous THF (80 mL) was cooled to $0{ }^{\circ} \mathrm{C}$ and tetrabutylammonium fluoride [1M solution in THF (78.9 $\mathrm{mL}, 78.9 \mathrm{mmol})]$ was added. The reaction mixture was heated to reflux for 3 hours. The reaction mixture was then quenched with $\mathrm{H}_{2} \mathrm{O}(150 \mathrm{~mL})$, and 
extracted with $\mathrm{CH}_{2} \mathrm{Cl}_{2}(3 \times 100 \mathrm{~mL})$. The combined organic extracts were dried $\left(\mathrm{Na}_{2} \mathrm{SO}_{4}\right)$ and concentrated under reduced pressure to provide a yellow oil which was purified by column chromatography on silica gel eluting with [hexane/EtOAc (3:1)]. The alcohol 15 was obtained as white solid. Yield $6.82 \mathrm{~g} \mathrm{(72 \% ).}$

15: $R_{f}=0.26$ [hexane/EtOAc (3:1)]; $\mathrm{mp} 129-131{ }^{\circ} \mathrm{C}$ (hexane); $[\alpha]_{\mathrm{D}}{ }^{22}=-8.8(c=$ 0.5, $\mathrm{CHCl}_{3}$ ); IR (neat) v 2924, 2867, 1069, 1048, 1039, 987, 923, 897, $760 \mathrm{~cm}^{-1}$; ${ }^{1} \mathrm{H}$ NMR $\left(300 \mathrm{MHz}, \mathrm{CDCl}_{3}\right) \delta 4.16-4.00(\mathrm{~m}, 1 \mathrm{H}), 3.75(\mathrm{~d}, J=6.7 \mathrm{~Hz}, 1 \mathrm{H}), 3.66(\mathrm{t}$, $J=6.8 \mathrm{~Hz}, 1 \mathrm{H}), 3.46(\mathrm{dd}, J=7.4,5.2 \mathrm{~Hz}, 2 \mathrm{H}), 1.91-1.43(\mathrm{~m}, 9 \mathrm{H}), 0.99(\mathrm{~s}, 3 \mathrm{H})$; ${ }^{13} \mathrm{C}$ NMR $\left(75 \mathrm{MHz}, \mathrm{CDCl}_{3}\right) \delta 80.8,76.4,71.5,40.3,40.1,31.3,30.2,25.8,24.3$, 23.6; MS (EI) m/z (\%) 186 (5), 150 (10), 133 (35), 107 (20), 93 (100), 91 (80), 79 (95), 77 (60), 55 (75); HRMS (EI) calcd for $\mathrm{C}_{10} \mathrm{H}_{16} \mathrm{O}_{2}$ : 168.1154. Found 168.1150; Anal. Calcd for $\mathrm{C}_{10} \mathrm{H}_{16} \mathrm{O}_{2}$ : $\mathrm{C}, 71.39 ; \mathrm{H}, 9.59$. Found $\mathrm{C}, 71.26 ; \mathrm{H}, 9.52$.

(1R,6S)-6-(((2,3-Dimethylbutan-2-yl)dimethylsilyl)oxy)-2-methylcyclohexa2,4-dienol (16) ${ }^{2}$<smiles>CC1=CC=CC([OH2+])C1O</smiles>

Diol $2(0.9 \mathrm{~g}, 7.13 \mathrm{mmol})$ was recrystallized from EtOAc and dissolved in dry DMF $(20 \mathrm{~mL})$. Imidazole $(0.56 \mathrm{~g}, 8.28 \mathrm{mmol})$ was added to the stirring mixture, followed by dimethylthexylchlorosilane $(1.65 \mathrm{~mL}, 8.42 \mathrm{mmol})$ and the mixture was allowed to react at $-20{ }^{\circ} \mathrm{C}$ for 23 hours. The reaction mixture was then diluted with $\mathrm{Et}_{2} \mathrm{O}(50 \mathrm{~mL})$ and washed with brine $(3 \times 25 \mathrm{~mL})$. The brine was backextracted with $\mathrm{Et}_{2} \mathrm{O}(3 \times 25 \mathrm{~mL})$ and the combined organic extracts were washed with sat. $\mathrm{CuSO}_{4}(3 \times 25 \mathrm{~mL})$, water $(30 \mathrm{~mL})$ and brine $(30 \mathrm{~mL})$. The combined organic extracts were dried $\left(\mathrm{Na}_{2} \mathrm{SO}_{4}\right)$ and concentrated under reduced pressure to give a yellow oil, which was purified by column chromatography on silica gel (10\% deactivated with $\mathrm{H}_{2} \mathrm{O}$ ) with [hexane/based washed EtOAc (95:5)]. The 
product 16 was obtained as yellow oil. Yield $1.73 \mathrm{~g}(91 \%)$. Spectral data were in agreement with previously published data.

16: $R_{f}=0.72$ [hexane/EtOAc (9:1)]; $[\alpha]_{\mathrm{D}}^{22}=69.5\left(c=0.5, \mathrm{CHCl}_{3}\right)\left(\right.$ lit. $^{2}[\alpha]_{\mathrm{D}}{ }^{22}=$ 86.11 $\left(c=1.26, \mathrm{CHCl}_{3}\right) ;{ }^{1} \mathrm{H}$ NMR $\left(300 \mathrm{MHz}, \mathrm{CDCl}_{3}\right) \delta 5.87$ (ddd, $J=9.6,5.3,1.6$ $\mathrm{Hz}, 1 \mathrm{H}), 5.74(\mathrm{~d}, J=5.4 \mathrm{~Hz}, 1 \mathrm{H}), 5.62(\mathrm{dd}, J=9.6,2.6 \mathrm{~Hz}, 1 \mathrm{H}), 4.56-4.39(\mathrm{~m}$, $1 \mathrm{H}), 3.89(\mathrm{t}, J=5.3 \mathrm{~Hz}, 1 \mathrm{H}), 2.63(\mathrm{~d}, J=4.8 \mathrm{~Hz}, 1 \mathrm{H}), 1.94(\mathrm{~s}, 3 \mathrm{H}), 1.75-1.55(\mathrm{~m}$, $1 \mathrm{H}), 1.03-0.77(\mathrm{~m}, 14 \mathrm{H}), 0.16(\mathrm{~d}, J=6.2 \mathrm{~Hz}, 7 \mathrm{H})$.

\section{(((1S,6R)-6-(Allyloxy)-5-methylcyclohexa-2,4-dien-1-yl)oxy)(2,3-} dimethylbutan-2-yl)dimethylsilane (17)<smiles>C=CCOC1C(C)=CC=CC1O</smiles>

A solution of silyl ether $16(1.07 \mathrm{~g}, 3.99 \mathrm{mmol})$ in dry THF $(30 \mathrm{~mL})$ was added dropwise to a stirring slurry of $\mathrm{NaH}(0.28 \mathrm{~g}, 6.98 \mathrm{mmol})$ in dry THF $(10 \mathrm{~mL})$ at 0 ${ }^{\circ} \mathrm{C}$. The resulting mixture was stirred for 10 minutes at this temperature, which was followed by the rapid addition of allylbromide $(0.45 \mathrm{~mL}, 5.19 \mathrm{mmol})$. The mixture was allowed to warm to room temperature and after five hours of stirring the reaction mixture was quenched with $\mathrm{H}_{2} \mathrm{O}(10 \mathrm{~mL})$ and extracted with $\mathrm{Et}_{2} \mathrm{O}$ (3 $x 25 \mathrm{~mL})$. The combined organic extracts were washed with $\mathrm{H}_{2} \mathrm{O}(30 \mathrm{~mL})$, brine $(3 \times 25 \mathrm{~mL})$ and dried $\left(\mathrm{Na}_{2} \mathrm{SO}_{4}\right)$. Concentration under reduced pressure provided a yellow oil, which was purified by column chromatography on silica gel $(10 \%$ deactivated with $\mathrm{H}_{2} \mathrm{O}$ ) eluting with [hexane/EtOAc (15:1)]. The product 17 was obtained as a yellow oil. Yield $0.88 \mathrm{~g}(65 \%)$.

17: ${ }^{1} \mathrm{H}$ NMR $\left(300 \mathrm{MHz}, \mathrm{CDCl}_{3}\right) \delta 6.26(\mathrm{dd}, J=8.2,6.9 \mathrm{~Hz}, 1 \mathrm{H}), 5.96(\mathrm{dd}, J=6.1$, $4.9 \mathrm{~Hz}, 1 \mathrm{H}), 5.69(\mathrm{dd}, J=8.3,1.3 \mathrm{~Hz}, 1 \mathrm{H}), 4.14(\mathrm{q}, J=7.1 \mathrm{~Hz}, 2 \mathrm{H}), 4.03$ (dd, $J=$ 7.6, $4.8 \mathrm{~Hz}, 1 \mathrm{H}$ ), $3.62(\mathrm{~s}, 1 \mathrm{H}), 3.48(\mathrm{dt}, J=6.8,2.0 \mathrm{~Hz}, 1 \mathrm{H}), 3.35$ (d, $J=6.8 \mathrm{~Hz}$, 
1H), $2.28(\mathrm{~d}, J=3.9 \mathrm{~Hz}, 1 \mathrm{H}), 1.85-1.46(\mathrm{~m}, 9 \mathrm{H}), 1.41-1.13(\mathrm{~m}, 17 \mathrm{H}), 0.99-0.69$ $(\mathrm{m}, 25 \mathrm{H}),-0.01-0.26 \quad(\mathrm{~m}, 11 \mathrm{H})$.

\section{(-)-(2,3-Dimethylbutan-2-yl)dimethyl(((3aS,7S)-3a-methyl-2,3,3a,6,7,7a-} hexahydro-3,6-methanobenzofuran-7-yl)oxy)silane (18)

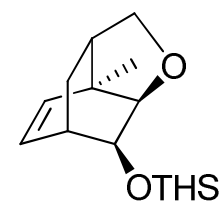

A solution of silyl ether $17(1.43 \mathrm{~g}, 4.63 \mathrm{mmol})$ in dry THF $(30 \mathrm{~mL})$ was heated to reflux for 2 hours. After the reaction was deemed to be complete, the solvent was removed under reduced pressure to give a light yellow oil, which was purified by column chromatography on silica gel, eluting with [hexane/EtOAc (15:1)]. The product 18 was obtained as a yellow oil. Yield $1.18 \mathrm{~g}(83 \%)$.

18: $R_{f}=0.61$ [hexane/EtOAc $(9: 1)$ ]; $[\alpha]_{\mathrm{D}}{ }^{22}=-61.8\left(c=0.5, \mathrm{CHCl}_{3}\right)$; IR (neat) $v$ $3041,2949,2872,1250,1127,1101,912,888,860,832,776 \mathrm{~cm}^{-1} ;{ }^{1} \mathrm{H}$ NMR (300 $\left.\mathrm{MHz}, \mathrm{CDCl}_{3}\right) \delta 6.23(\mathrm{dd}, J=8.2,6.9 \mathrm{~Hz}, 1 \mathrm{H}), 5.66(\mathrm{dd}, J=8.3,1.4 \mathrm{~Hz}, 1 \mathrm{H}), 4.00$ (dd, $J=7.5,4.9 \mathrm{~Hz}, 1 \mathrm{H}$ ), $3.61(\mathrm{~d}, J=7.6 \mathrm{~Hz}, 1 \mathrm{H}$ ), 3.46 (dt, $J=6.8,2.0 \mathrm{~Hz}, 1 \mathrm{H}$ ), $3.33(\mathrm{~d}, J=6.8 \mathrm{~Hz}, 1 \mathrm{H}), 2.39-2.18(\mathrm{~m}, 1 \mathrm{H}), 1.83-1.39(\mathrm{~m}, 4 \mathrm{H}), 1.22(\mathrm{~s}, 3 \mathrm{H}), 0.97-$ $0.77(\mathrm{~m}, 13 \mathrm{H}), 0.16--0.02(\mathrm{~m}, 6 \mathrm{H}) ;{ }^{13} \mathrm{C}$ NMR $\left(75 \mathrm{MHz}, \mathrm{CDCl}_{3}\right) \delta 134.8,132.2$, 77.6, 74.4, 72.1, 45.9, 40.2, 36.8, 34.4, 34.0, 25.1, 21.2, 20.6, 20.2, 18.7, 18.5, 2.7, -3.4; MS (EI) m/z (\%) 223 (100), 205 (39), 193 (52), 131 (55), 91 (32), 75 (62), 73 (29); HRMS (EI) calcd for $\mathrm{C}_{18} \mathrm{H}_{32} \mathrm{O}_{2} \mathrm{Si}$ (loss of $\mathrm{C}_{6} \mathrm{H}_{13}$ ): 223.1154. Found 223.1155; Anal. Calcd for $\mathrm{C}_{18} \mathrm{H}_{32} \mathrm{O}_{2} \mathrm{Si}$ : C, 70.07; $\mathrm{H}, 10.45$. Found $\mathrm{C}, 70.37 ; \mathrm{H}$, 10.45 .

(-)-(2,3-Dimethylbutan-2-yl)dimethyl(((3aS,7S)-3a-methyloctahydro-3,6methanobenzofuran-7-yl)oxy)silane (19) 


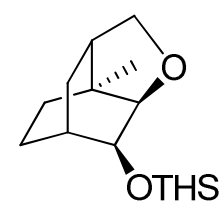

The Diels-Alder adduct 18 (1.93 g, $6.25 \mathrm{mmol})$ was dissolved in absolute ethanol $(100 \mathrm{~mL})$ and $10 \% \mathrm{Pd} / \mathrm{C}$ was added (250 $\mathrm{mg}, 0.23 \mathrm{mmol})$. The mixture was hydrogenated in Parr shaker at 20 psi of $\mathrm{H}_{2}$ for 3 hours. The reaction mixture was then filtered through Celite ${ }^{\mathrm{TM}}$ and the solvent was removed under reduced pressure to provide $1.84 \mathrm{~g}$ of a colorless oil, which was purified by column chromatography on silica gel, eluting with [hexane/EtOAc (15:1)]. The product 19 was obtained as a colorless oil. Yield $1.81 \mathrm{~g}(93 \%)$.

19: $R_{f}=0.65$ [hexane/EtOAc $\left.(9: 1)\right] ;[\alpha]_{\mathrm{D}}^{22}=-17.7\left(c=0.5, \mathrm{CHCl}_{3}\right)$; IR (neat) $v$ 2926, 2866, 1249, 1130, 1099, 830, $773 \mathrm{~cm}^{-1} ;{ }^{1} \mathrm{H}$ NMR $\left(300 \mathrm{MHz}, \mathrm{CDCl}_{3}\right) \delta 4.08-$ $3.95(\mathrm{~m}, 1 \mathrm{H}), 3.69(\mathrm{~d}, J=6.7 \mathrm{~Hz}, 1 \mathrm{H}), 3.57(\mathrm{~d}, J=6.7 \mathrm{~Hz}, 1 \mathrm{H}), 3.41(\mathrm{~d}, J=7.5$ $\mathrm{Hz}, 1 \mathrm{H}), 1.85-1.38(\mathrm{~m}, 9 \mathrm{H}), 0.99-0.70(\mathrm{~m}, 15 \mathrm{H}), 0.18-0.01(\mathrm{~m}, 6 \mathrm{H}) ;{ }^{13} \mathrm{C}$ NMR $(75$ $\left.\mathrm{MHz}, \mathrm{CDCl}_{3}\right) \delta 81.8,75.9,73.9,40.7,40.0,34.5,32.2,31.1,26.0,25.1,24.5$, 23.9, 20.6, 20.3, 18.7, 18.5, -2.6, -3.3; MS (EI) m/z (\%) 226 (29), 225 (92), 223 (33), 196 (29), 195 (100), 133 (28), 119 (44), 91 (31), 75 (86), 73 (46), 59 (30); HRMS (El) calcd for $\mathrm{C}_{18} \mathrm{H}_{34} \mathrm{O}_{2} \mathrm{Si}$ (loss of $\mathrm{C}_{6} \mathrm{H}_{13}$ ): 225.1311. Found 225.1315; Anal. Calcd for $\mathrm{C}_{18} \mathrm{H}_{34} \mathrm{O}_{2} \mathrm{Si}: \mathrm{C}, 69.62 ; \mathrm{H}, 11.04$. Found C, 70.05; H, 10.98.

\section{(-)-(3aS,6R)-3a-Methylhexahydro-3,6-methanobenzofuran-7(7aH)-one (20)}



Alcohol 15 (330 mg, $1.96 \mathrm{mmol}$ ) was dissolved in dry $\mathrm{CH}_{2} \mathrm{Cl}_{2}$ (30 mL) and pyridinium chlorochromate $(2.11 \mathrm{~g}, 9.81 \mathrm{mmol})$ was added. The mixture was 
allowed to stir for 20 hours at room temperature. The reaction mixture was then diluted with $\mathrm{Et}_{2} \mathrm{O}(30 \mathrm{~mL})$ and filtered through a short plug of silica gel. The solvent was removed under reduced pressure, and the title compound was recrystallized from hot hexane $(20 \mathrm{~mL})$ affording 20 as a white solid. Yield 298 $\mathrm{mg}(91 \%)$.

20: $R_{f}=0.43$ [hexane/EtOAc (3:1)]; $\mathrm{mp} 105-106{ }^{\circ} \mathrm{C}$ (hexane); $[\alpha]_{\mathrm{D}}^{22}=-25.7(c=$ $0.5, \mathrm{CHCl}_{3}$ ); IR (neat) v 2955, 2931,2874, 1715, 1237,1028, 1000, 884, $486 \mathrm{~cm}^{-1}$; ${ }^{1} \mathrm{H}$ NMR $\left(300 \mathrm{MHz}, \mathrm{CDCl}_{3}\right) \delta 4.15(\mathrm{dd}, J=7.9,4.3 \mathrm{~Hz}, 1 \mathrm{H}), 3.60-3.44(\mathrm{~m}, 2 \mathrm{H})$, $2.23(\mathrm{~d}, J=2.6 \mathrm{~Hz}, 1 \mathrm{H}), 2.15$ (dd, $J=9.5,4.3 \mathrm{~Hz}, 1 \mathrm{H}$ ), 2.04 (dd, $J=13.3,9.5 \mathrm{~Hz}$, $1 \mathrm{H}), 1.93-1.53(\mathrm{~m}, 5 \mathrm{H}), 1.05(\mathrm{~s}, 3 \mathrm{H}) ;{ }^{13} \mathrm{C}$ NMR $\left(75 \mathrm{MHz}, \mathrm{CDCl}_{3}\right) \delta 212.8,84.0$, 76.2, 43.1, 39.9, 38.7, 31.4, 26.2, 23.2, 22.6; MS (EI) m/z (\%) 166 (89), 138 (57), 120 (75), 109 (44), 107 (87), 105 (56), 96 (37), 95 (55), 93 (74), 92 (66), 91 (62), 83 (84), 82 (32), 81 (54), 80 (30), 79 (73), 77 (45), 68 )30), 67 (100), 55 (63), 53 (53); HRMS (EI) calcd for $\mathrm{C}_{10} \mathrm{H}_{14} \mathrm{O}_{2}: 166.0994$. Found 166.0986; Anal. Calcd for $\mathrm{C}_{10} \mathrm{H}_{14} \mathrm{O}_{2}$ : C, 72.26; $\mathrm{H}, 8.49$. Found $\mathrm{C}, 72.23 ; \mathrm{H}, 8.49$.

(E)-4-Methyl-N-(3a-methylhexahydro-3,6-methanobenzofuran-7(7aH)ylidene)benzenesulfonamide (21)



To a stirring solution of ketone $20(20 \mathrm{mg}, 0.1203 \mathrm{mmol})$ in dry THF $(3 \mathrm{~mL})$ was added titanium(IV) isopropoxide $(102.57 \mathrm{mg}, 0.361 \mathrm{mmol}$ ) followed by the rapid addition of 4-toluenesulfonamide $(22.66 \mathrm{mg}, 0.132 \mathrm{mmol})$. The mixture was heated to reflux for 89 hours. The reaction was then quenched with brine and extracted with EtOAc $(3 \times 30 \mathrm{~mL})$. The combined organic extracts were dried $\left(\mathrm{Na}_{2} \mathrm{SO}_{4}\right)$, concentrated under reduced pressure, and the resulting residue was 
filtered through a short plug of silica gel eluting with [hexane/EtOAc (3:1)]. The solvent was evaporated under reduced pressure affording $\mathbf{2 1}$ as a colorless oil.

\section{(3aS)-3a-Methyl-2'-tosylhexahydro-2H-spiro[3,6-methanobenzofuran-7,3'-}

\section{[1,2]oxaziridine] (22)}

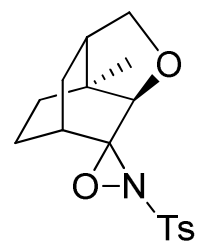

Imine 21 (50 mg, $0.156 \mathrm{mmol}$ ) was dissolved in toluene $(3 \mathrm{~mL})$ and an aqueous solution of $\mathrm{K}_{2} \mathrm{CO}_{3}(83.1 \mathrm{mg}, 0.6 \mathrm{mmol})$ was added. The mixture was stirred vigorously and an aqueous solution of Oxone ${ }^{\mathrm{TM}}(105.3 \mathrm{mg}, 0.342 \mathrm{mmol})$ was added dropwise. The mixture was stirred for 6 hours at room temperature. The aqueous layer was separated, extracted with toluene $(3 \times 3 \mathrm{~mL})$ and the combined organic extracts were washed with $10 \%$ aqueous solution of $\mathrm{Na}_{2} \mathrm{SO}_{3}$, dried over anhydrous $\mathrm{MgSO}_{4}$ and purified by column chromatography on silica gel $\left(10 \%\right.$ deactivated with $\left.\mathrm{H}_{2} \mathrm{O}\right)$ eluting with [hexane/EtOAc (4:1)]. Yield $30 \mathrm{mg}$ $(57 \%)$.

22: $R_{f}=0.21$ [hexane/EtOAc $\left.(4: 1)\right] ;[\alpha]_{\mathrm{D}}^{22}=-63.6\left(c=1.285, \mathrm{CHCl}_{3}\right)$; IR (neat) $v$ 2929, 2874, 1349, 1164, 1115, 892, 814, 709, 671, 659, 566, 529; ${ }^{1} \mathrm{H}$ NMR $(300$ $\left.\mathrm{MHz}, \mathrm{CDCl}_{3}\right) \delta 5.83(\mathrm{ddd}, J=9.6,5.3,1.6 \mathrm{~Hz}, 1 \mathrm{H}), 5.74-5.66(\mathrm{~m}, 1 \mathrm{H}), 5.59$ (dd, $J=9.6,2.7 \mathrm{~Hz}, 1 \mathrm{H}), 4.48-4.35(\mathrm{~m}, 1 \mathrm{H}), 3.86(\mathrm{t}, J=5.4 \mathrm{~Hz}, 1 \mathrm{H}), 2.59(\mathrm{~d}, J=4.9$ $\mathrm{Hz}, 1 \mathrm{H}), 1.90(\mathrm{~s}, 1 \mathrm{H}), 1.72-1.56(\mathrm{~m}, 1 \mathrm{H}), 0.94-0.78(\mathrm{~m}, 2 \mathrm{H}), 0.14(\mathrm{~s}, 3 \mathrm{H}) ;{ }^{13} \mathrm{C}$ NMR $\left(75 \mathrm{MHz}, \mathrm{CDCl}_{3}\right) \delta 145.45,145.25,134.92,129.79,129.70,128.82$, 128.39, 97.89, 93.73, 84.60, 81.86, 76.12, 76.06, 41.77, 40.96, 39.46, 39.26, $31.71,31.54,31.50,25.70,24.84,23.70,23.20,22.83,22.75,21.70 ;$ MS (EI) $\mathrm{m} / \mathrm{z}$ (\%) 679 (44), 662 (39), 661 (100), 360 (25), 358 (48), 342 (25), 320 (28). 


\section{Asymmetric hydroxylation}

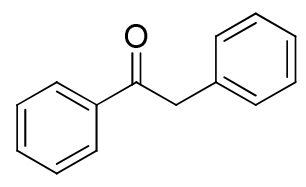

23

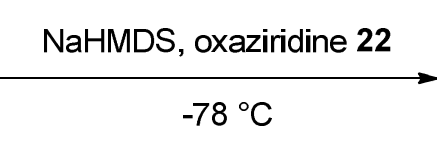

$-78^{\circ} \mathrm{C}$

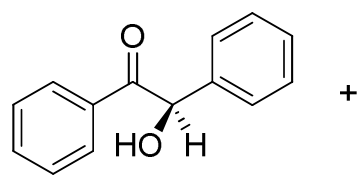

24<smiles>O=C(c1ccccc1)[C@H](O)c1ccccc1</smiles>

25

Sodium bis(trimethylsilyl)amide $(0.12 \mathrm{~mL}, 0.05 \mathrm{mmol})$ was cooled in acetone/dry ice bath to $-78^{\circ} \mathrm{C}$ and a solution of deoxybenzoin 23 (18 $\left.\mathrm{mg}, 0.092 \mathrm{mmol}\right)$ in THF $(1 \mathrm{~mL})$ was added dropwise. The mixture was stirred at this temperature for 30 minutes, and a solution of oxaziridine $22(46 \mathrm{mg}, 0.138 \mathrm{mmol})$ in THF $(1 \mathrm{~mL})$ was added. The reaction was monitored by TLC for 4 hours, before being quenched with $\mathrm{NH}_{4} \mathrm{Cl}$, and the mixture was allowed to warm to room temperature. The aqueous solution was extracted by $\mathrm{Et}_{2} \mathrm{O}(3 \times 5 \mathrm{~mL})$, and the combined organic extracts were dried $\left(\mathrm{Na}_{2} \mathrm{SO}_{4}\right)$, concentrated under reduced pressure, and the resulting residue was purified by column chromatography on silica gel eluting with [hexane/EtOAc (5:1)]. Yield $17 \mathrm{mg}(85 \%)$.

$24+25: R_{f}=0.46[$ hexane/EtOAc $(5: 1)] ;[\alpha]_{\mathrm{D}}^{22}=18.5\left(c=0.83, \mathrm{CHCl}_{3}\right) ; \underline{\mathrm{ee}=16}$ \%; ${ }^{1} \mathrm{H}$ NMR (400 MHz, $\left.\mathrm{CDCl}_{3}\right) \delta 7.91$ (dd, $\left.J=5.2,3.4 \mathrm{~Hz}, 2 \mathrm{H}\right), 7.66-7.09(\mathrm{~m}$, $8 \mathrm{H}), 5.96(\mathrm{~s}, 1 \mathrm{H}), 4.56(\mathrm{~s}, 1 \mathrm{H}) ;{ }^{13} \mathrm{C}$ NMR $\left(101 \mathrm{MHz}, \mathrm{CDCl}_{3}\right) \delta$ 199.0, 139.0, 133.9, 129.7, 128.7, 128.6, 127.8, 76.23.

The same reaction was run with (-) Davis Reagent for comparison. $[\alpha]_{\mathrm{D}}^{22}=-78.5$ $\left(c=0.83, \mathrm{CHCl}_{3}\right)$; ee $=\sim 95 \%($ estimated $)$.

(7S,7aR)-3a-Methyloctahydro-3,6-methanobenzofuran-7-yl 2-phenylacetate (26) 


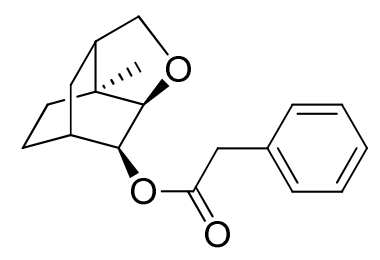

Alcohol 15 (0.185 mg, $1.1 \mathrm{mmol})$ was dissolved in anhydrous $\mathrm{CH}_{2} \mathrm{Cl}_{2}(5 \mathrm{~mL})$ and $\mathrm{NaH}(60 \%$ in oil dispersion, $48 \mathrm{mg}, 1.2 \mathrm{mmol})$ was added at $0{ }^{\circ} \mathrm{C}$. The reaction mixture was stirred for one hour before phenylacetyl chloride $(0.26 \mathrm{~mL}, 2.0$ mmol) was added, and the reaction mixture was then stirred for $16 \mathrm{~h}$ at room temperature. The reaction mixture was then quenched with a saturated solution of $\mathrm{NH}_{4} \mathrm{Cl}$ and extracted with EtOAc $(3 \times 25 \mathrm{~mL})$. The combined organic extracts were concentrated under reduced pressure and the residue was purified by column chromatography on silica gel eluting with [hexane/EtOAc (6:1)] providing 26 as a colorless oil. Yield $233 \mathrm{mg}(74 \%)$.

26: $R_{f}=0.78$ [hexane/EtOAc (3:1)]; $[\alpha]_{\mathrm{D}}^{22}=-55.1\left(c=1.0, \mathrm{CHCl}_{3}\right)$; IR (neat) $v$ $2931,2870,1728,1452,1356,1218,1165,1025,702 ;{ }^{1} \mathrm{H}$ NMR $(400 \mathrm{MHz}$, $\left.\mathrm{CDCl}_{3}\right) \delta 7.62-7.07(\mathrm{~m}, 5 \mathrm{H}), 4.56(\mathrm{~d}, J=6.2 \mathrm{~Hz}, 1 \mathrm{H}), 3.90(\mathrm{t}, J=24.7 \mathrm{~Hz}, 2 \mathrm{H})$, $3.77-3.52(\mathrm{~m}, 2 \mathrm{H}), 3.15(\mathrm{~d}, J=7.8 \mathrm{~Hz}, 1 \mathrm{H}), 1.94-1.06(\mathrm{~m}, 8 \mathrm{H}), 0.84(\mathrm{~d}, J=$ $63.4 \mathrm{~Hz}, 3 \mathrm{H}) ;{ }^{13} \mathrm{C}$ NMR $\left(101 \mathrm{MHz}, \mathrm{CDCl}_{3}\right) \delta 171.2,134.5,129.5,129.4,128.6$, 128.4, 126.8, 78.7, 76.3, 76.0, 41.4, 40.9, 40.5, 39.8, 32.3, 27.2, 25.7, 24.1, 23.5; MS (El) m/z (\%) 286 (25), 167 (15), 150 (20), 118 (45), 105 (20), 91 (100), 77 (20); HRMS (EI) calcd for $\mathrm{C}_{18} \mathrm{H}_{22} \mathrm{O}_{3}$ : 286.1569. Found 286.1561; Anal. Calcd for $\mathrm{C}_{18} \mathrm{H}_{22} \mathrm{O}_{3}$ : C, 75.50; H, 7.74. Found C, 75.36; H, 7.63.

(7S,7aR)-3a-Methyloctahydro-3,6-methanobenzofuran-7-yl 2phenylpropanoate (27)

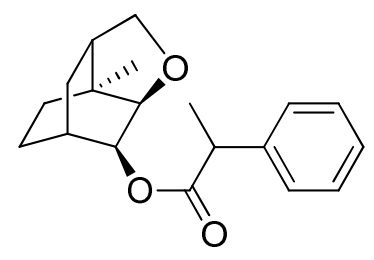


A solution of freshly prepared LDA $(0.82 \mathrm{mmol})$ in THF was added dropwise to a solution of phenylacetyl ester $26(0.21 \mathrm{~g}, 0.74 \mathrm{mmol})$ in THF $(7 \mathrm{~mL})$ at $-78{ }^{\circ} \mathrm{C}$. The reaction mixture was stirred for one hour before the dropwise addition of methyl iodide $(0.05 \mathrm{~mL}, 0.82 \mathrm{mmol})$. The reaction mixture was then slowly warmed to $-20{ }^{\circ} \mathrm{C}$, before being quenched with a saturated solution of $\mathrm{NH}_{4} \mathrm{Cl}$ and extracted with EtOAc $(3 \times 25 \mathrm{~mL})$. The combined organic extracts were concentrated under reduced pressure, and the resulting residue was purified by column chromatography on silica gel eluting with [hexane/EtOAc (6:1)] yielding $187 \mathrm{mg}(84 \%)$ of 27 as a colorless oil.

27: $R_{f}=0.83$ [hexane/EtOAc (3:1)]; IR (neat) $v$ 2930, 2870, 1729, 1493, 1376, 1205, 1165, 1063, 728; ${ }^{1} \mathrm{H}$ NMR $\left(400 \mathrm{MHz}, \mathrm{CDCl}_{3}\right) \delta 7.41-7.29(\mathrm{~m}, 4 \mathrm{H}), 7.29-$ $7.22(\mathrm{~m}, 1 \mathrm{H}), 4.61-4.44(\mathrm{~m}, 1 \mathrm{H}), 4.06-3.89(\mathrm{~m}, 1 \mathrm{H}), 3.89-3.69(\mathrm{~m}, 2 \mathrm{H}), 3.26$ (d, $J=7.8 \mathrm{~Hz}, 1 \mathrm{H}), 2.82(\mathrm{~d}, J=7.9 \mathrm{~Hz}, 1 \mathrm{H}), 1.94-1.34(\mathrm{~m}, 8 \mathrm{H}), 0.95(\mathrm{~d}, J=3.8$ $\mathrm{Hz}, 3 \mathrm{H}), 0.91(\mathrm{~s}, 3 \mathrm{H}) ;{ }^{13} \mathrm{C}$ NMR $\left(101 \mathrm{MHz}, \mathrm{CDCl}_{3}\right) \delta$ 174.2, 173.7, 140.90, $140.86,129.5,128.7,128.4,128.3,128.0,127.8,126.9$, 126. 8, 78.83, 78.81, 76.3, 76.1, 75.7, 45.6, 45.5, 40.5, 39.8, 39.6, 32.3, 32.2, 27.2, 27.1, 25.6, 25.5, 24.2, 23.47, 23.45, 18.7, 18.0; MS (EI) m/z (\%) 300 (10), 210 (10), 167 (10), 151 (20), 132 (20), 105 (100), 91 (75), 79 (20); HRMS (EI) calcd for $\mathrm{C}_{19} \mathrm{H}_{24} \mathrm{O}_{3}$ : 300.1725. Found 300.1729; Anal. Calcd for $\mathrm{C}_{19} \mathrm{H}_{24} \mathrm{O}_{3}$ : C, 75.97; $\mathrm{H}, 8.05$. Found C, 76.25; H, 8.01.

\section{2-Phenylpropanoic acid (28)}



Ester $27(0.145 \mathrm{~g}, 0.48 \mathrm{mmol})$ was dissolved in $25 \%$ aqueous $\mathrm{MeOH}(4 \mathrm{~mL})$, lithium hydroxide monohydrate $(100 \mathrm{mg}, 2.4 \mathrm{mmol})$ was added and the reaction mixture was stirred at room temperature for $16 \mathrm{~h}$. The solvent was then removed 
under reduced pressure and the resulting residue was purified by column chromatography on silica gel eluting with [hexane/EtOAc (6:1)] yielding $62 \mathrm{mg}$ $(86 \%)$ of 28 as a colorless oil. The spectroscopic data correspond to those previously reported in the literature.

28: $R_{f}=0.10$ [hexane/EtOAc $\left.(1: 1)\right] ;[\alpha]_{\mathrm{D}}^{22}=-3.6\left(c=1.0, \mathrm{CHCl}_{3}\right)((S)-(+)-2-$ phenylpropionic acid - lit. $\left.{ }^{10}[\alpha]_{\mathrm{D}}{ }^{22}=+72.6\left(c=1.6, \mathrm{CHCl}_{3}\right)\right) ;{ }^{1} \mathrm{H}$ NMR $(300 \mathrm{MHz}$, $\left.\mathrm{CDCl}_{3}\right) \delta 7.39-7.25(\mathrm{~m}, 5 \mathrm{H}), 3.76(\mathrm{q}, J=7.2 \mathrm{~Hz}, 1 \mathrm{H}), 1.54(\mathrm{~d}, J=7.2 \mathrm{~Hz}, 3 \mathrm{H})$; ${ }^{13} \mathrm{C} \mathrm{NMR}\left(75 \mathrm{MHz}, \mathrm{CDCl}_{3}\right) \delta 180.8,139.8,128.7,127.6,127.4,45.4,18.1$.

\section{(7S,7aR)-3a-Methyloctahydro-3,6-methanobenzofuran-7-yl acrylate (29)}

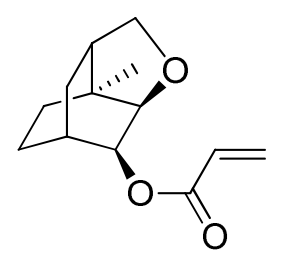

Alcohol 15 (60 mg, $0.36 \mathrm{mmol})$ was dissolved in anhydrous THF $(5 \mathrm{~mL})$ before triethylamine $(0.08 \mathrm{~mL}, 0.54 \mathrm{mmol})$ and acryloyl chloride $(0.04 \mathrm{~mL}, 0.47 \mathrm{mmol})$ were added, and the reaction mixture was stirred for $2 \mathrm{~h}$ at room temperature. The reaction mixture was then quenched with a saturated aqueous solution of $\mathrm{NH}_{4} \mathrm{Cl}$ and extracted with EtOAc $(3 \times 25 \mathrm{~mL})$. The combined organic extracts were concentrated under reduced pressure and the resulting residue was purified by column chromatography on silica gel eluting with [hexane/EtOAc (6:1)] providing 29 as a colorless oil. Yield $69 \mathrm{mg}(87 \%)$.

29: $R_{f}=0.68$ [hexane/EtOAc (3:1)]; $[\alpha]_{\mathrm{D}}{ }^{22}=-111.5\left(c=1.0, \mathrm{CHCl}_{3}\right)$; IR (neat) $v$ 2930, 2871, 1719, 1634, 1453, 1269, 1192, 1060, 860; ${ }^{1} \mathrm{H}$ NMR $(300 \mathrm{MHz}$, $\left.\mathrm{CDCl}_{3}\right) \delta 6.41(\mathrm{dd}, J=17.3,1.6 \mathrm{~Hz}, 1 \mathrm{H}), 6.15(\mathrm{dd}, J=17.3,10.3 \mathrm{~Hz}, 1 \mathrm{H}), 5.80$ (dd, $J=10.3,1.6 \mathrm{~Hz}, 1 \mathrm{H}), 4.64(\mathrm{dd}, J=6.4,1.6 \mathrm{~Hz}, 1 \mathrm{H}), 4.06-3.99(\mathrm{~m}, 1 \mathrm{H})$, $3.97(\mathrm{~d}, J=6.5 \mathrm{~Hz}, 1 \mathrm{H}), 3.38$ (d, $J=7.8 \mathrm{~Hz}, 1 \mathrm{H}), 1.93-1.46(\mathrm{~m}, 7 \mathrm{H}), 0.94$ (s, $3 \mathrm{H}) ;{ }^{13} \mathrm{C} \mathrm{NMR}\left(75 \mathrm{MHz}, \mathrm{CDCl}_{3}\right) \delta 165.9,130.3,128.6,78.9,76.3,76.1,40.5$, 
39.8, 32. 5, 27.3, 25.8, 24.2, 23.5; MS (EI) m/z (\%) 222 (5), 150 (40), 135 (10), 121 (25), 109 (35), 93 (55), 79 (40), 55 (100); HRMS (EI) calcd for $\mathrm{C}_{13} \mathrm{H}_{18} \mathrm{O}_{3}$ : 222.1256. Found 222.1254; Anal. Calcd for $\mathrm{C}_{13} \mathrm{H}_{18} \mathrm{O}_{3}$ : C, 70.24; $\mathrm{H}, 8.16$. Found C, $70.34 ; \mathrm{H}, 8.23$.

(1S, 2S, 4S)-(3aS,7S)-3a-Methyloctahydro-3,6-methanobenzofuran-7-yl bicyclo[2.2.2] oct-5-ene-2-carboxylate (30a) and (1R,2R,4R)-(3aS,7S)-3aMethyloctahydro-3,6-methanobenzofuran-7-yl bicyclo[2.2.2]oct-5-ene-2carboxylate (30b)

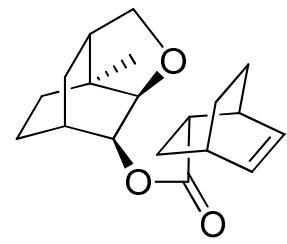

$30 a$

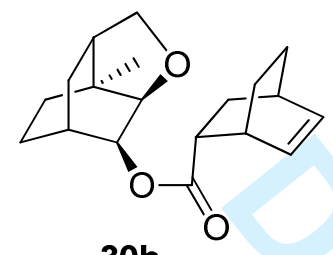

$30 \mathrm{~b}$

Ester 29 (129 mg, $0.58 \mathrm{mmol})$ was dissolved in toluene $(1 \mathrm{~mL})$ before the addition of 1,3-cyclohexadiene $(0.7 \mathrm{~mL}, 7.2 \mathrm{mmol})$, and the mixture was heated in sealed tube for 15 hours. The volatiles were then removed under reduced pressure and the resulting residue was purified by column chromatography on silica gel eluting with [hexane/EtOAc (12:1)]. Two isomers 30a $(47.6 \mathrm{mg})$ and $30 \mathrm{~b}$ $(53.5 \mathrm{mg})$ were obtained.

30a: light yellow oil; $R_{f}=0.37$ [hexane/EtOAc $(12: 1)$ ]; $[\alpha]_{\mathrm{D}}{ }^{22}=-45.7(c=0.5$, $\mathrm{CHCl}_{3}$ ); IR (neat) $v 2928,2866,1730,1162,1050,899,695 \mathrm{~cm}^{-1} ;{ }^{1} \mathrm{H}$ NMR (300 $\left.\mathrm{MHz}, \mathrm{CDCl}_{3}\right) \delta 6.31(\mathrm{t}, J=6.9 \mathrm{~Hz}, 1 \mathrm{H}), 6.25-6.11(\mathrm{~m}, 1 \mathrm{H}), 4.49(\mathrm{t}, J=7.1 \mathrm{~Hz}$, 1H), 4.01 (ddd, $J=13.4,8.1,5.3 \mathrm{~Hz}, 1 \mathrm{H}$ ), 3.91 (t, $J=7.8 \mathrm{~Hz}, 1 \mathrm{H}$ ), $3.47-3.31$ (m, 1H), 2.94 (d, $J=3.7 \mathrm{~Hz}, 1 \mathrm{H}$ ), 2.67 (ddd, $J=11.3,6.8,3.8 \mathrm{~Hz}, 1 \mathrm{H}$ ), 2.59 (dd, $J=10.0,7.1 \mathrm{~Hz}, 1 \mathrm{H}), 1.91-1.81(\mathrm{~m}, 2 \mathrm{H}), 1.74-1.67(\mathrm{~m}, 2 \mathrm{H}), 1.67-1.39(\mathrm{~m}$, 14H), $1.00-0.90(\mathrm{~m}, 4 \mathrm{H}) ;{ }^{13} \mathrm{C}$ NMR $\left(101 \mathrm{MHz}, \mathrm{CDCl}_{3}\right) \delta 175.5,134.9,131.7$, 79.0, 76.2, 75.6, 42.7, 40.5, 39.9, 32.5, 32.4, 30.0, 29.5, 27.4, 25.8, 25.5, 24.4, 24.2, 23.5; MS (EI) m/z (\%) 167 (76), 151 (67), 150 (26), 107 (61), 93 (28), 91 
(25), 79 (100), 77 (28); HRMS (EI) calcd for $\mathrm{C}_{19} \mathrm{H}_{23} \mathrm{O}_{3}$ : 302.1882. Found 302.1879; Anal. Calcd for $\mathrm{C}_{19} \mathrm{H}_{23} \mathrm{O}_{3}$ : C, 75.46; $\mathrm{H}, 8.67$. Found $\mathrm{C}, 75.21 ; \mathrm{H}, 8.47$. 30b: white solid; $R_{f}=0.46$ [hexane/EtOAc (12:1)]; mp 97-99 ${ }^{\circ} \mathrm{C}$ (hexane/EtOAc); $[\alpha]_{\mathrm{D}}^{22}=-95.97\left(c=1.0, \mathrm{CHCl}_{3}\right)$; IR (neat) $v 3048,2935,2870,1727,1187,1168$, $1048,913,690 \mathrm{~cm}^{-1} ;{ }^{1} \mathrm{H}$ NMR $\left(300 \mathrm{MHz}, \mathrm{CDCl}_{3}\right) \delta 6.38-6.24(\mathrm{~m}, 1 \mathrm{H}), 6.18$ (dd, $J=10.8,3.7 \mathrm{~Hz}, 1 \mathrm{H}), 4.46(\mathrm{~d}, J=6.5 \mathrm{~Hz}, 1 \mathrm{H}), 4.09-3.96(\mathrm{~m}, 1 \mathrm{H}), 3.93(\mathrm{~d}, J=$ $6.5 \mathrm{~Hz}, 1 \mathrm{H}), 3.38(\mathrm{~d}, J=7.7 \mathrm{~Hz}, 1 \mathrm{H}), 2.96(\mathrm{~d}, J=3.4 \mathrm{~Hz}, 1 \mathrm{H}), 2.71-2.52(\mathrm{~m}$, 2H), $1.90-1.75(\mathrm{~m}, 3 \mathrm{H}), 1.92-1.74(\mathrm{~m}, 3 \mathrm{H}), 1.70$ (ddd, $J=11.3,6.0,3.9 \mathrm{~Hz}$, 2H), $1.67-1.56(\mathrm{~m}, 4 \mathrm{H}), 1.55-1.38(\mathrm{~m}, 4 \mathrm{H}), 0.92(\mathrm{~d}, J=5.1 \mathrm{~Hz}, 3 \mathrm{H}) ;{ }^{13} \mathrm{C} N M R$ $\left(101 \mathrm{MHz}, \mathrm{CDCl}_{3}\right) \delta 175.0,134.6,131.9,79.0,76.1,75.7,42.5,40.5,39.9,32.7$, 32.6, 29.7, 29.3, 27.4, 25.8, 25.7, 24.4, 24.2, 23.5; MS (EI) m/z (\%) 167 (75), 151 (74), 121 (25), 107 (64), 93 (29), 81 (25), 79 (100), 77 (26); HRMS (EI) calcd for $\mathrm{C}_{19} \mathrm{H}_{23} \mathrm{O}_{3}:$ 302.1882. Found 302.1877; Anal. Calcd for $\mathrm{C}_{19} \mathrm{H}_{23} \mathrm{O}_{3}: \mathrm{C}, 75.46 ; \mathrm{H}$, 8.67. Found $\mathrm{C}, 75.17 ; \mathrm{H}, 8.67$.

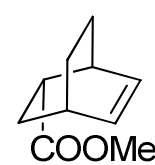

$31 \mathbf{a}$

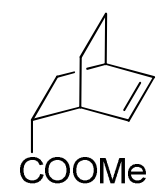

$31 b$

(1S,4S)-Methyl bicyclo[2.2.2]oct-5-ene-2-carboxylate (31a) $(1 R, 4 R)$-Methyl bicyclo[2.2.2]oct-5-ene-2-carboxylate (31b) ${ }^{11}$

Diels-alder adduct 30a (53.5 mg, $0.18 \mathrm{mmol}$ ) was dissolved in $\mathrm{MeOH}(2 \mathrm{~mL})$ under an argon atmosphere. After the addition of sodium methoxide $(0.7 \mathrm{~mL} 25 \%$ $\mathrm{v} / \mathrm{v}$ in $\mathrm{MeOH}$ ) was the resulting mixture stirred for the next $4 \mathrm{~h}$ at room temperature. After the completion, acidic Dowex exchange resin was added to neutralize the $\mathrm{pH}$. The resin was filtered out and solvent was removed under the reduced pressure. The residue was purified using column chromatography on silica gel eluting with [hexane/EtOAc (4:1)]. Ester 31a was obtained as light yellow oil $(14.7 \mathrm{mg}$ ) yield $59.12 \%$. NMR analysis confirmed that the ester is 
mixture of exo- and endo- (1:10). Identical procedure was applied to produce $31 \mathrm{~b}$ from $30 \mathrm{~b}$.

31a: $R_{f}=0.86$ [hexane/EtOAc (4:1)]; $[\alpha]_{D}^{20}=+1.2\left(c=0.5, \mathrm{CHCl}_{3}\right) ;{ }^{1} \mathrm{H}$ NMR $(400$ $\left.\mathrm{MHz}, \mathrm{CDCl}_{3}\right) \delta 6.33(\mathrm{dd}, J=19.7,12.2 \mathrm{~Hz}, 1 \mathrm{H}), 6.15(\mathrm{t}, J=7.3 \mathrm{~Hz}, 1 \mathrm{H}), 3.69(\mathrm{~s}$, $1 \mathrm{H}), 3.63(\mathrm{~s}, 3 \mathrm{H}), 2.92(\mathrm{~d}, J=3.4 \mathrm{~Hz}, 1 \mathrm{H}), 2.68-2.53(\mathrm{~m}, 2 \mathrm{H}), 1.80-1.61(\mathrm{~m}$, 2H), $1.56(\mathrm{ddd}, J=21.0,9.6,6.8 \mathrm{~Hz}, 2 \mathrm{H}), 1.51-1.41(\mathrm{~m}, 1 \mathrm{H}), 1.39-1.12(\mathrm{~m}$, $5 \mathrm{H}), 0.92-0.76(\mathrm{~m}, 1 \mathrm{H})$.

31b: $R_{f}=0.86$ [hexane/EtOAc (4:1)]; $[\alpha]_{D}^{20}=-39.5\left(c=0.5, \mathrm{CHCl}_{3}\right) ;{ }^{1} \mathrm{H}$ NMR $(400$ $\left.\mathrm{MHz}, \mathrm{CDCl}_{3}\right) \delta 6.33(\mathrm{dd}, J=19.7,12.2 \mathrm{~Hz}, 1 \mathrm{H}), 6.15(\mathrm{t}, J=7.3 \mathrm{~Hz}, 1 \mathrm{H}), 3.69(\mathrm{~s}$, $1 \mathrm{H}), 3.63(\mathrm{~s}, 3 \mathrm{H}), 2.92(\mathrm{~d}, J=3.4 \mathrm{~Hz}, 1 \mathrm{H}), 2.68-2.53(\mathrm{~m}, 2 \mathrm{H}), 1.80-1.61(\mathrm{~m}$, 2H), 1.56 (ddd, $J=21.0,9.6,6.8 \mathrm{~Hz}, 2 \mathrm{H}), 1.51-1.41(\mathrm{~m}, 1 \mathrm{H}), 1.39-1.12(\mathrm{~m}$, $5 \mathrm{H}), 0.92-0.76(\mathrm{~m}, 1 \mathrm{H})$. This compound was a mixture of $5 \%$ exo- and $95 \%$ endo-isomers.

$(1 S, 2 S, 4 S)$-Bicyclo[2.2.2]oct-5-en-2-yImethanol (32a) ${ }^{12,14}$



Diels-alder adduct 30a (104 mg, $0.34 \mathrm{mmol}$ ) was dissolved in anhydrous THF (5 $\mathrm{mL})$. After the addition of Red-Al $(0.43 \mathrm{~g}, 1.38 \mathrm{mmol})$, the resulting mixture was stirred for $3 \mathrm{~h}$ at room temperature. After the reaction was deemed to be complete, a saturated aqueous solution of Rochelle's salt was added and the mixture was extracted with EtOAc $(3 \times 25 \mathrm{~mL})$. The combined organic extracts were concentrated under reduced pressure and the residue was purified by column chromatography on silica gel eluting with [hexane/EtOAc (4:1)] yielding $40 \mathrm{mg}(84 \%)$ of $32 \mathrm{a}$ as a colorless oil. The spectroscopic data correspond to those previously reported in the literature. ${ }^{12,14}$

32a: $R_{f}=0.20$ [hexane/EtOAc (4:1)]; $[\alpha]_{D}{ }^{20}=-10.2\left(c=0.9\right.$, EtOH); ${ }^{1} \mathrm{H}$ NMR $(400$ $\left.\mathrm{MHz}, \mathrm{CDCl}_{3}\right) \delta 6.27(\mathrm{t}, J=7.4 \mathrm{~Hz}, 1 \mathrm{H}), 6.13(\mathrm{t}, J=7.3 \mathrm{~Hz}, 1 \mathrm{H}), 3.37-3.16(\mathrm{~m}$, 
2H), $2.61(\mathrm{~d}, J=3.9 \mathrm{~Hz}, 1 \mathrm{H}), 2.56-2.43(\mathrm{~m}, 1 \mathrm{H}), 2.01-1.79(\mathrm{~m}, 1 \mathrm{H}), 1.67$ (ddd, $J=12.4,9.7,2.8 \mathrm{~Hz}, 1 \mathrm{H}), 1.62-1.40(\mathrm{~m}, 3 \mathrm{H}), 1.40-1.16(\mathrm{~m}, 2 \mathrm{H}), 0.75(\mathrm{ddt}, J=$ 12.4, 5.4, $2.8 \mathrm{~Hz}, 1 \mathrm{H}) ;{ }^{13} \mathrm{C} \mathrm{NMR}\left(75 \mathrm{MHz}, \mathrm{CDCl}_{3}\right) \delta 135.0,131.7,67.5,40.5$, $31.4,30.2,29.7,25.9,24.7 ; t_{\mathrm{R}}$ (HPLC, chiral column IA, 98:2 Hept/iPrOH, $15{ }^{\circ} \mathrm{C}$, $0.5 \mathrm{~mL} / \mathrm{min}$ ) $22.72 \mathrm{~min}$.

$(1 R, 2 R, 4 R)$-Bicyclo[2.2.2]oct-5-en-2-ylmethanol (32b) ${ }^{13,14}$

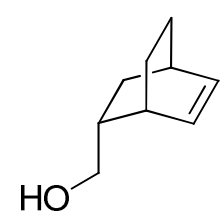

Diels-alder adduct 30b (103 mg, $0.34 \mathrm{mmol}$ ) was dissolved in anhydrous THF (5 $\mathrm{mL})$. After the addition of Red-Al $(0.43 \mathrm{~g}, 1.38 \mathrm{mmol})$, the resulting mixture was stirred for $3 \mathrm{~h}$ at room temperature. After the reaction was deemed to be complete, a saturated aqueous solution of Rochelle's salt was added and the mixture was extracted with EtOAc $(3 \times 25 \mathrm{~mL})$. The combined organic extracts were concentrated under reduced pressure and the residue was purified by column chromatography on silica gel eluting with [hexane/EtOAc (4:1)] yielding $38 \mathrm{mg}(80 \%)$ of $\mathbf{3 2 b}$ as a colorless oil. The spectroscopic data correspond to those previously reported in the literature. ${ }^{13,14}$

32b: $R_{f}=0.20$ [hexane/EtOAc (4:1)]; $[\alpha]_{\mathrm{D}}{ }^{20}=+7.7\left(c=0.9\right.$, EtOH); ${ }^{1} \mathrm{H}$ NMR $(400$ $\left.\mathrm{MHz}, \mathrm{CDCl}_{3}\right) \delta 6.28(\mathrm{t}, J=7.3 \mathrm{~Hz}, 1 \mathrm{H}), 6.14(\mathrm{t}, J=7.2 \mathrm{~Hz}, 1 \mathrm{H}), 3.36-3.14(\mathrm{~m}$, 2H), $2.58(\mathrm{~d}, J=18.7 \mathrm{~Hz}, 1 \mathrm{H}), 2.51(\mathrm{~d}, J=2.7 \mathrm{~Hz}, 1 \mathrm{H}), 1.98-1.78(\mathrm{~m}, 1 \mathrm{H}), 1.68$ (ddd, $J=12.3,9.7,2.6 \mathrm{~Hz}, 1 \mathrm{H}), 1.62-1.39(\mathrm{~m}, 3 \mathrm{H}), 1.39-1.14(\mathrm{~m}, 2 \mathrm{H}), 0.84-$ $1.14(\mathrm{~m}, 1 \mathrm{H}) ;{ }^{13} \mathrm{C}$ NMR $\left(75 \mathrm{MHz}, \mathrm{CDCl}_{3}\right) \delta 135.1,131.7,67.5,40.5,31.3,30.2$, 29.7, 25.9, 24.7; $t_{\mathrm{R}}$ (HPLC, chiral column IA, 98:2 Hept/iPrOH, $15{ }^{\circ} \mathrm{C}, 0.5$ $\mathrm{mL} / \mathrm{min}) 22.0 \mathrm{~min}$. 


\section{Bicyclo[2.2.2] oct-5-en-2-ylmethanol (rac-32) ${ }^{14}$}

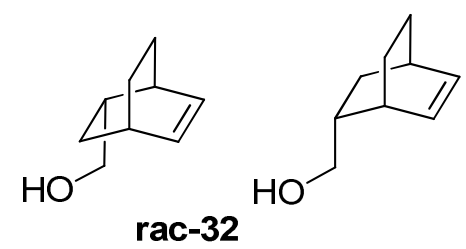

Methyl acrylate $(2.0 \mathrm{~mL}, 22 \mathrm{mmol})$ was dissolved in toluene $(5 \mathrm{~mL})$ before the addition of 1,3-cyclohexadiene $(3.5 \mathrm{~mL}, 31 \mathrm{mmol})$. The mixture was then heated in a sealed tube for $15 \mathrm{~h}$.Volatiles were then removed under reduced pressure and the resulting residue was directly used in the subsequent step. The resultant methyl ester $(0.2 \mathrm{~g}, 1.2 \mathrm{mmol})$ was dissolved in anhydrous THF (5 mL). After the addition of Red-Al $(1.0 \mathrm{~g}, 3.20 \mathrm{mmol})$, the resulting mixture was stirred for $3 \mathrm{~h}$ at room temperature. After the reaction was deemed to be complete, a saturated aqueous solution of Rochelle's salt was added and the mixture was extracted with EtOAc $(3 \times 40 \mathrm{~mL})$. The combined organic extracts were concentrated under reduced pressure and the resulting residue was purified by column chromatography on silica gel eluting with [hexane/EtOAc (4:1)] yielding $130 \mathrm{mg}$ $(80 \%)$ of rac-32 as a colorless oil. Spectral data were in agreement with previously published results. ${ }^{14}$

rac-32: $R_{f}=0.20$ [hexane/EtOAc (4:1)]; $[\alpha]_{\mathrm{D}}{ }^{22}=-0.8\left(c=0.5, \mathrm{CHCl}_{3}\right) ;{ }^{1} \mathrm{H} \mathrm{NMR}$ $\left(400 \mathrm{MHz}, \mathrm{CDCl}_{3}\right) \delta 6.28(\mathrm{t}, J=7.4 \mathrm{~Hz}, 1 \mathrm{H}), 6.13(\mathrm{t}, J=7.4 \mathrm{~Hz}, 1 \mathrm{H}), 3.36-3.14$ (m, 2H), $2.58(\mathrm{~d}, J=18.7 \mathrm{~Hz}, 1 \mathrm{H}), 2.51(\mathrm{~d}, J=2.7 \mathrm{~Hz}, 1 \mathrm{H}), 1.98-1.78(\mathrm{~m}, 1 \mathrm{H})$, 1.68 (ddd, $J=12.3,9.7,2.6 \mathrm{~Hz}, 1 \mathrm{H}), 1.62-1.39(\mathrm{~m}, 3 \mathrm{H}), 1.39-1.14(\mathrm{~m}, 2 \mathrm{H})$, $0.84-1.14(\mathrm{~m}, 1 \mathrm{H}) ;{ }^{13} \mathrm{C}$ NMR $\left(75 \mathrm{MHz} \mathrm{CDCl}_{3}\right) \delta 135.1,131.7,67.5,40.5,31.3$, 30.2, 29.7, 25.9, 24.7; $t_{R}$ (HPLC, chiral column IA, 98:2 Hept/iPrOH, $15{ }^{\circ} \mathrm{C}, 0.5$ $\mathrm{mL} / \mathrm{min}) 22.3$ and $23.0 \mathrm{~min}$.

\section{References}


[1] Hudlicky, T.; Seoane, G.; Pettus, T. J. Org. Chem. 1989, 54, 4239.

[2] Hudlicky, T.; Boros, C. H.; Boros, E. E. Synthesis 1992, 174.

[3] Butora, G.; Gum, A. G.; Hudlicky, T.; Abboud, K. A. Synthesis 1998, 275.

[4] Varghese, V; Hudlicky, T. Angew. Chem. Int. Ed. 2014, 53, 4355.

[5] Hudlicky, T.; Boros, E. E.; Boros, C. H. Synlett 1992, 391.

[6] Hudlicky, T.; Boros, E. E.; Boros, C. H. Tetrahedron: Asymmetry 1993, 4, 1365.

[7] Zylstra, G. J.; Gibson, D. T. J. Biol. Chem. 1989, 264, 14940.

[8] Hudlicky, T.; Luna, H.; Barbieri, G.; Kwart, L. D. J. Am. Chem. Soc. 1988, $110,4735$.

[9] Davis, F. A.; Sheppard, A. C.; Chen, B. C.; Haque, M. S. J. Am. Chem. Soc. 1990, 112, 6679.

[10] Milne, J.; Storz, T.; Colyer, J. T.; Thiel, O. R.; Dilmeghani Seran, M.; Larsen, R. D.; Murry, J. A. J. Org. Chem. 2011, 76, 9519.

[11] (a) Brown, M. K.; Corey, E. J. Org. Lett. 2010, 12, 172; (b) Ohwada, T.; Uchiyama, M.; Tsuji, M.; Okamoto, I.; Shudo, K. Chem. Pharm. Bull. 1996, 44, 296.

[12] Ishihara, K.; Fushimi, M. J. Am. Chem. Soc. 2008, 130, 7532.

[13] Kitagawa, O.; Izawa, H.; Sato, K.; Dobashi, A.; Taguchi, T. J. Org. Chem. 1998, 63, 2634.

[14] Arai,Y.; Takadoi, M.; Koizumi, T. Chem. Pharm. Bull. 1988, 36, 4162.

[15] Schrödinger Release 2016-2: MacroModel, version 11.2, Schrödinger, LLC, New York, NY, 2016.

[16] Schrödinger Release 2016-2: Maestro, version 10.6, Schrödinger, LLC, New York, NY, 2016 was used to generate illustrations.

[17] Bach, R., D.; Andres, J. L; Davis, F. A. J. Org. Chem. 1992, 57, 613.

[18] Bondi, A. J. Phys. Chem. 1964, 68, 441. 